\title{
Studi perbandingan hasil pengukuran resistansi pembumian menggunakan tiga metode pengukuran yang berbeda
}

\author{
Sunarto $^{1^{*}}$, Trisnawiyana ${ }^{2}$ \\ 1,2 Jurusan Teknik Elektro, Politeknik Negeri Bandung \\ Jln. Gegerkalong Hilir, Ds. Ciwaruga, Kab. Bandung Barat, Jawa Barat 40559, Indonesia \\ ${ }^{1 *}$ soen@ @polban.ac.id, ${ }^{2}$ trisnawiyana @ polban.ac.id
}

\begin{abstract}
ABSTRAK
Sistem pembumian merupakan proteksi untuk keselamatan dengan menyalurkan arus gangguan ke bumi dan nilai resistansi pembumian harus sekecil mungkin. Oleh karena itu, untuk mengetahui besarnya nilai resistansi pembumian perlu dilakukan pengukuran resistansi elektrode pembumian. Untuk mengukur resistansi elektrode pembumian diperlukan alat ukur earth tester. Pengukuran menggunakan earth tester terdapat dua metode yaitu metode tiga titik dan metode dua titik. Metode tiga titik menggunakan tiga konektor pada earth tester yaitu konektor C, P, dan E, sedangkan metode dua titik hanya dua konektor yang digunakan yaitu konektor $\mathrm{C}$ dan E, sumber dari luar diinjeksikan ke konektor C. Selain kedua metode tersebut bisa menggunakan metode Volt-Ampere untuk mengukur resistansi pembumian. Metode ini menggunakan dua alat ukur yaitu Voltmeter dan Ampere meter. Tujuan penelitian ini adalah untuk membandingkan hasil pengukuran resistansi pembumian menggunakan tiga metode tersebut. Hasil penelitian menunjukkan bahwa pengukuran resistansi pembumian yang paling baik adalah metode tiga titik menggunakan alat ukur earth tester. Hal ini karena tidak pada metode ini tidak diperlukan sumber dari luar dan paling banyak mengahsilkan hasil pengukuran yang nilainya homogen.
\end{abstract}

Kata kunci: resistansi pembumian, elektrode pembumian, Volt-Ampere meter, earth tester

\section{ABSTRACT}

The earthing system is a protection for safety by transmitting fault current to earth and the value of the earth resistance must be as small as possible. Therefore, to determine the value of the earth resistance, it is necessary to measure the resistance of the grounding electrode. To measure the resistance of the grounding electrode, an earth tester is needed. There are two methods of measuring using an earth tester, namely the threepoint method and the two-point method. The three-point method uses three connectors on the earth tester, namely connectors $C, P$, and $E$, while the two-point method only uses two connectors, namely connectors $C$ and $E$, an external source is injected into connector $C$. Ampere to measure earth resistance. This method uses two measuring instruments, namely Voltmeter and Ampere meter. The purpose of this study was to compare the results of measuring ground resistance using these three methods. The results showed that the best measurement of earth resistance is the three-point method using an earth tester. This is because this method does not require an external source and most results in measurement results whose values are homogeneous.

Keywords: earth resistance, earth electrode, Volt-Ampere meter, earth tester

\section{PENDAHULUAN}

Dalam PUIL 2011 disebutkan bahwa pengukuran resistansi pembumian harus dilakukan lebih dari satu kali sampai didapat hasil pengukuran yang rata (homogen). Jika hasil pengukuran tidak didapat nilai yang sama maka pengukuran harus diulang. Dalam PUIL 2000 maupun PUIL 2011 hanya diberi contoh cara pengukuran resistansi pembumian dengan metode Volt-Ampere yang menggunakan dua alat ukur yaitu Voltmeter dan Ampere meter dimana kedua alat ukur tersebut masing-masing mempunyai kelas ketelitian tertentu sehingga akan mempengaruhi hasil pengukuran. Dengan adanya permasalahan tersebut, maka perlu dilakukan penelitian pengukuran resistansi pembumian dengan dua metode yang lain untuk membandingkan hasil pengukuran dengan metode Volt-Ampere [1]-[4].

Dalam melakukan pengukuran resistansi pembumian pada elektrode yang telah terpasang maka dibutuhkan suatu alat ukur earth tester sebagai instrumen atau acuan dalam melakukan pengukuran 
resistansi elektrode pembumian. Metode yang digunakan adalah tiga titik yaitu tiga konektor yang ada pada alat ukur earth tester dipakai dalam melakukan pengukuran. Konektor E dihubungkan ke elektrode yang akan diukur menggunakan kabel warna hijau, konektor P dihubung ke elektrode bantu 1 menggunakan kabel warna kuning, dan konektor $\mathrm{C}$ dihubungkan ke elektrode bantu 2 menggunakan kabel warna merah. Dalam penelitian yang pernah dilakukan [5] dan [6] hanya menggunakan metode tiga titik untuk pengukuran resistansi pembumian. Elektrode bantu 1 yang dihubungkan ke konektor $\mathrm{P}$ dan elektrode bantu 2 yang dihubungkan ke konektor $\mathrm{C}$ bisa dipindah-pindah dalam pengukuran resistansi pembumian sampai didapat nilai hasil pengukuran yang rata. Jarak antara elektrode yang diukur dengan elektrode bantu 1 minimal 5 meter, demikian juga jarak antara elektrode bantu 1 dan elektrode bantu 2.

Dalam penelitian lain yang pernah dilakukan untuk mengukur resistansi pembumian menggunakan alat ukur earth tester dengan dua metode yaitu metode tiga titik dan metode dua titik. Metode dua titik hanya memakai dua konektor dari tiga konektor yang ada pada alat ukur. Dua konektor yang dipakai adalah konektor $\mathrm{E}$ yang dihubungkan ke elektrode yang akan diukur resistansinya menggunakan kabel warna hujau, dan konektor $\mathrm{C}$ yang dihubungkan ke elektrode bantu menggunakan kabel warna merah. Metode dua titik ini memerlukan sumber dari luar, dipilih fasanya saja, dan diinjeksikan ke konektor C. Besarnya tegangan yang diinjeksikan disesuaikan dengan skala maksimum alat ukur, biasanya sebesar 30 VAC. Metode pengukuran dua titik biasanya dipakai untuk mengukur resistansi pembumian dimana posisi elektrode yang akan diukur lokasinya tidak memungkinkan untuk mebentang kabel secara leluasa misalnya di perumahan padat, atau di daerah perindustrian dimana sekitar lokasi elektrode pembumian yang akan diukur sudah tidak leluasa untuk menancapkan elektroda bantu [7], [8].

Penelitian terkait juga pernah dilakukan dalam pengukuran resistansi pembumian menggunakan metode Volt-Ampere. Pada metode ini ada tiga cara pengukuran yaitu dua titik, tiga titik, dan empat titik. Elektroda bantu yang diperlukan untuk pengukuran harus berjarak minimum 20 meter dari elektroda yang diukur jika elektroda pembumian terdiri dari elektroda batang, dan berjarak kira-kira 3 kali diameternya jika elektroda bumi terdiri dari elektroda pita (dalam bentuk cincin, radial, atau kombinasi). Pengukuran ini dilakukan dengan menggunakan alat ukur Voltmeter dan Ampere meter yang masing-masing mempunyai sumber sendiri. Penghantar bumi dari elektroda bumi yang akan diukur $\left(\mathrm{R}_{\mathrm{P}}\right)$ dihubungkan dengan penghantar fasa instalasi melalui gawai proteksi arus lebih, saklar, resistansi yang dapat diatur dari $20 \mathrm{Ohm}$ sampai $1000 \mathrm{Ohm}$, dan Ampere meter. Pada saat saklar dimasukkan, resistansi tersebut harus dalam kedudukan maksimum. Setelah saklar dimasukkan, resistansi diatur sedemikian rupa hingga Ampere meter dan Volt meter menunjukkan simpangan secukupnya. Hasil bagi dari dan arus yang ditunjukkan oleh instrumen ukur tersebut adalah resistansi pembumian yang diukur [9], [10].

Terdapat pula penelitian sebelumnya yang telah dilakukan terkait pengukuran resistansi pembumian yang menggunakan metode Volt-Ampere 4 titik, dimana elektroda pembumian yang diukur bisa $\mathrm{C} 1$ atau $\mathrm{C} 2$. Bila elektroda yang diukur adalah $\mathrm{C} 1$ maka $\mathrm{C} 2$ adalah elektroda bantu 1 dan sebaliknya. P1 dan P2 adalah elektroda bantu yang ke-2 dan ke-3. Seperti pada metode Volt-Ampere 3 titik pada metode ini elektroda yang diukur dihubungkan ke sumber. Resistansi pembumian dihitung dari yang terukur pada Volt meter dibagi arus yang terukur pada Ampere meter [11].

Penelitian ini bertujuan untuk membandingkan hasil pengukuran resistansi pembumian menggunakan tiga metode pengukuran yaitu pengukuran menggunakan earth tester metode tiga titik dan dua titik, dan metode Volt-Ampere. Metode Volt-Ampere yang digunakan dalam penelitian ini hanya menggunakan metode tiga titik. Perbedaan penelitian ini dengan penelitian sebelumnya adalah pada jumlah metode pengukuran yang digunakan. Dalam penelitian ini menggunakan tiga metode pengukuran, sedangkan pada penelitian sebelumnya hanya menggunakan dua metode dengan satu jenis alat ukur yang digunakan yaitu alat ukur earth tester metode tiga titik dan dua titik, dan ada penelitian yang menggunakan alat ukur Volt-Ampere metode empat titik dan tiga titik.

\section{METODE PENELITIAN}

Metode yang digunakan untuk meperoleh data dalam penelitian ini adalah metode eksperimental yang dilakukan di Laboratorium Instalasi Listrik Politeknik Negeri Bandung. Analisa data 
menggunakan metode komparatif yaitu membandingkan hasil pengukuran resistansi pembumian dengan tiga metode berbeda. Tahapan dalam penelitian ini dapat dilihat pada Gambar 1.

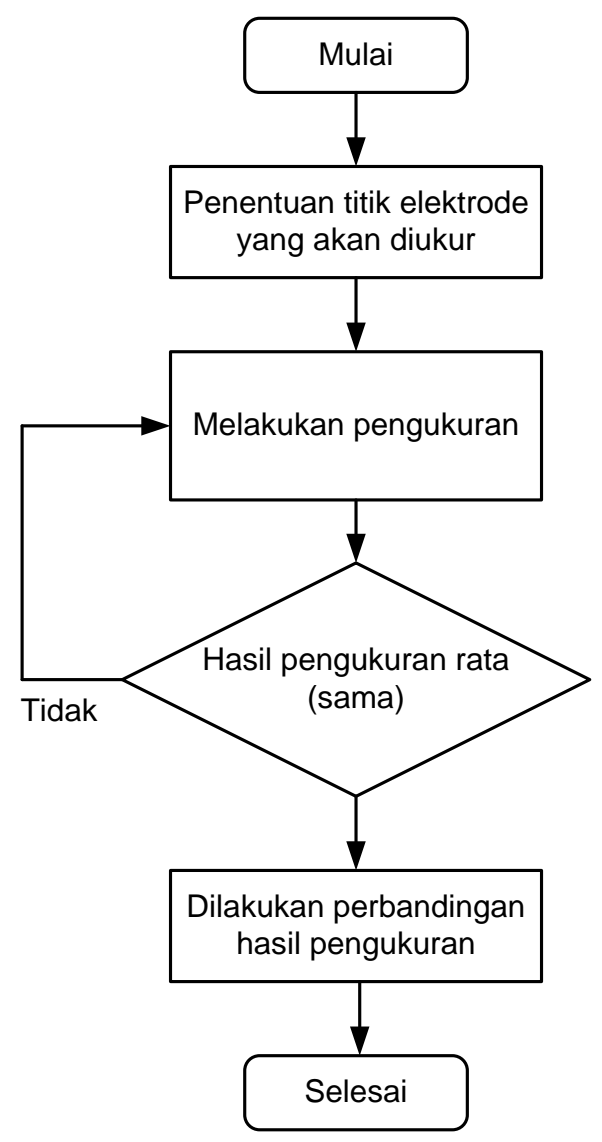

Gambar 1. Diagram alur penelitian

\subsection{Pengukuran Menggunakan Volt-Ampere Meter}

Dalam penelitian ini pengukuran resistansi pembumian menggunakan Volt-Ampere meter metode tiga titik. Pengukuran resistansi pembumian dengan metode tiga titik menggunakan dua elektroda bantu (T1 dan T2) dan elektroda T adalah elektroda pembumian yang diukur. Elektroda bantu T1 pada posisi tetap, sedangkan elektroda bantu T2 posisinya dipindah-pindah dalam tiga posisi (posisi di titik T1, titik X, dan titik Y) seperti pada Gambar 2. Arus bolak-balik satu fasa dengan nilai nominal dialirkan ke elektroda pembumian yang diukur (T). Jarak T dan T1 terhadap T2 tidak boleh melebihi $20 \mathrm{~m}$. Untuk memperoleh hasil pengukuran resistansi pembumian menggunakan Volt-Ampere dengan menggunakan rumus berikut:

$$
R=\frac{V}{I} \Omega
$$

dengan:

$\mathrm{R} \quad=$ Resistansi pembumian $(\Omega)$

$\mathrm{V} \quad$ = Tegangan yang terukur pada Volt meter (Volt)

$\mathrm{I} \quad=$ Arus listrik yang terukur pada Ampere meter (Ampere) 


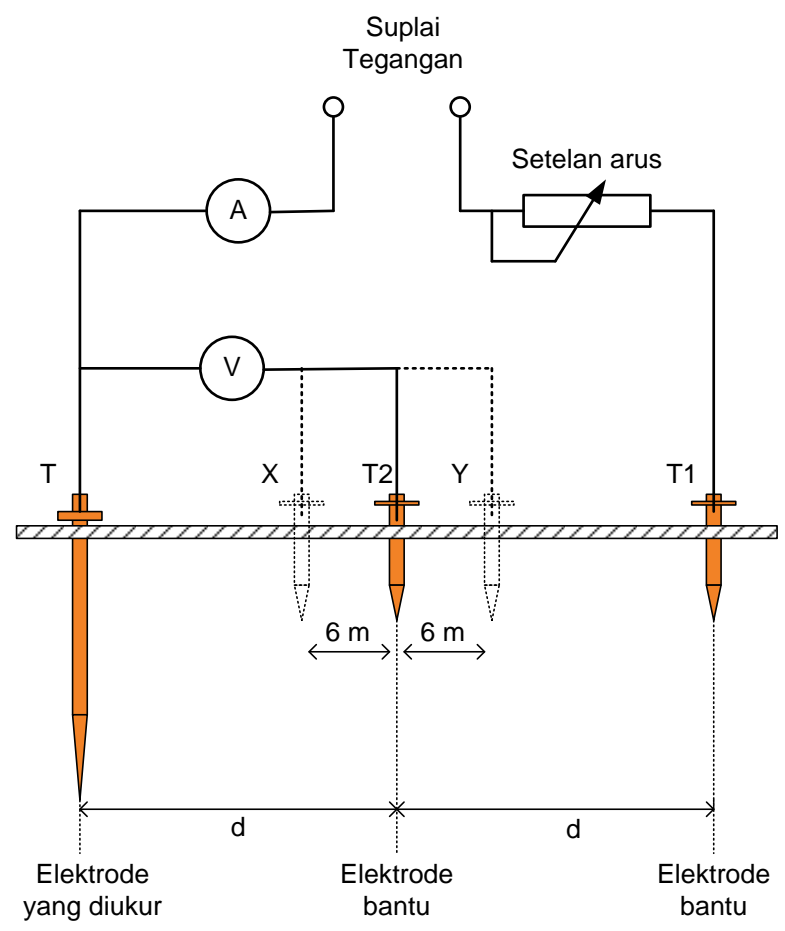

Gambar 2. Pengukuran resistansi pembumian metode tiga titik menggunakan Volt-Ampere

\subsection{Pengukuran Metode Dua Titik Menggunakan Earth Tester}

Pada pengukuran menggunakan earth tester metode dua titik hanya dua konektor pada earth tester yang digunakan yaitu konektor E dan konektor C. Konektor E dihubungkan ke elektroda pembumian yang akan diukur dan konektor $\mathrm{C}$ dihubungkan ke elektroda bantu dan tegangan $\mathrm{AC}$ (diambil bagian fasanya saja) diinjeksikan ke konektor C seperti pada Gambar 3.

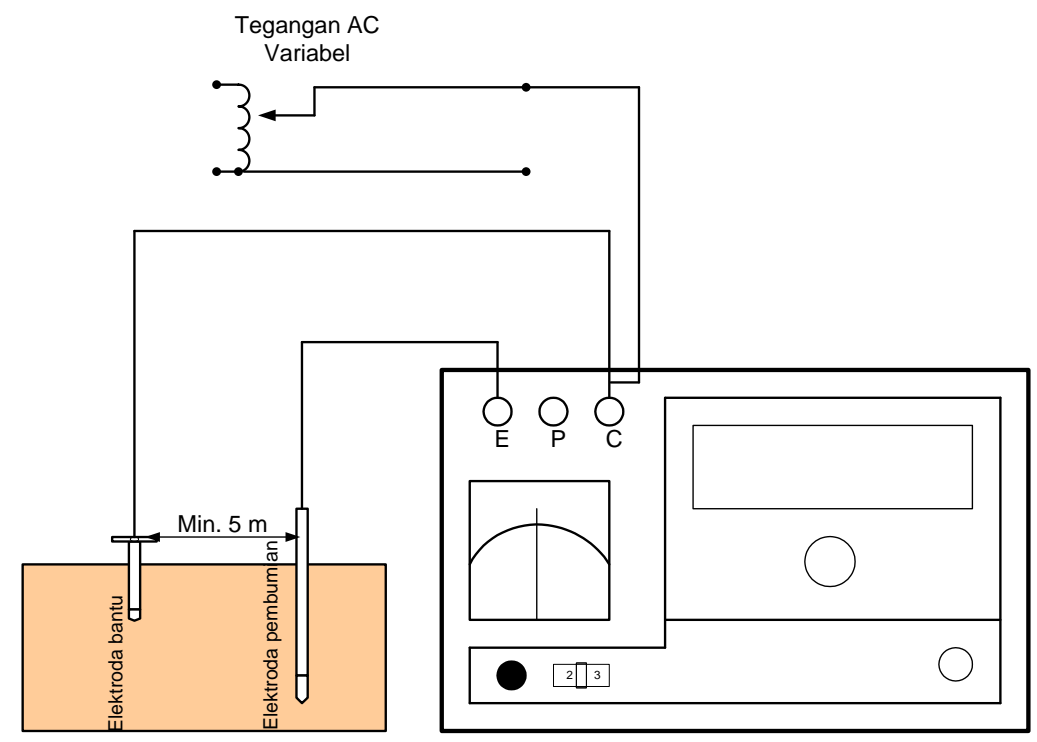

Gambar 3. Pengukuran resistansi pembumian metode dua titik menggunakan earth tester

\section{B. Pengukuran Metode Tiga Titik Menggunakan Earth Tester}

Pengukuran resistansi pembumian metode tiga titik dilakukan menggunakan earth tester. Tiga konektor E, P, dan $\mathrm{C}$ pada earth tester digunakan untuk pengukuran. Konektor E dihubungkan ke elektroda pembumian yang diukur, sedangkan konektor $\mathrm{P}$ dan $\mathrm{C}$ masing-masing dihubungkan ke elektroda bantu 1 dan 2. Pada metode pengukuran ini elektroda bantu 1 dan 2 dipindah-pindah untuk 
mendapatkan hasil pengukuran yang akurat yaitu hasil pengukuran yang nilainya sama. Metode pengukuran tiga titik menggunakan earth tester tidak perlu sumber tegangan dari luar. Sumber tegangan yang digunakan adalah baterai yang ada dalam alat ukur tersebut. Untuk lebih jelasnya, metode ini dapat dilihat pada Gambar 4.

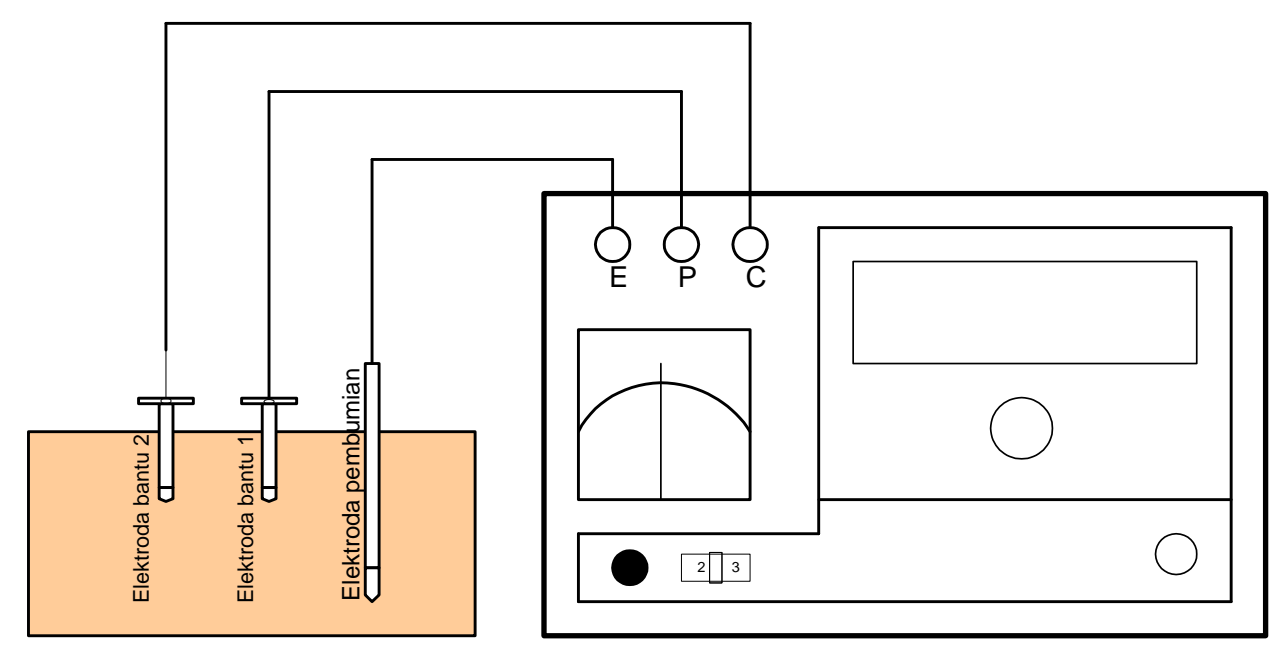

Gambar 4. Pengukuran resistansi pembumian metode tiga titik menggunakan earth tester

\section{HASIL DAN PEMBAHASAN}

Jumlah elektroda pembimian yang menjadi obyek pengukuran dalam penelitian ada 2 titik elektroda pembumian yaitu elektroda pembumian 1 dan elektroda pembumian 2, masing-masing adalah elektroda pembumian bentuk batang panjang 4 meter yang terbuat dari bahan tembaga. Pengukuran resistansi pembumian pada satu titik elektroda pembumian tidak bisa dilakukan dengan sekali pengukuran saja karena kondisi tiap titik tanah tidak sama dalam hal kelembaban dan kandungan mineralnya. Oleh karena itu, untuk mengukuar satu titik elektroda pembumian dilakukan beberapa kali pengukuran dengan cara memindah posisi elelktroda bantu. Elektroda bantu ini terbuat dari bahan baja anti korosi yang panjangnya kurang lebih $30-40 \mathrm{~cm}$. Dengan memindahkan posisi elektroda bantu tersebut brtujuan untuk mendapat titik yang kondisi tanahnya sama (homogen), sehingga didapat hasil pengukuran resistansi pembumian yang sama. Hasil pengukuran resistansi pembumian yang nilainya sama dipakai sebagai hasil pengukuran yang akurat.

Tabel 1. Hasil pengukuran dengan metode tiga titik menggunakan Volt-Ampere

\begin{tabular}{|c|c|c|c|c|c|c|c|}
\hline \multirow{2}{*}{ No. } & \multirow{2}{*}{$\begin{array}{c}\text { Posisi } \\
\text { elektroda } \\
\text { bantu T2 }\end{array}$} & \multicolumn{2}{|c|}{ Elektroda pembumian 1 } & \multicolumn{3}{c|}{ Elektroda pembumian 2 } \\
\cline { 3 - 8 } & $\begin{array}{c}\text { Drop } \\
\text { tegangan } \\
(\mathbf{V})\end{array}$ & $\begin{array}{c}\text { Arus } \\
\text { listrik } \\
(\mathbf{A})\end{array}$ & $\begin{array}{c}\text { Resistansi } \\
\text { pembumian } \\
(\mathbf{O h m})\end{array}$ & $\begin{array}{c}\text { Drop } \\
\text { tegangan } \\
(\mathbf{V})\end{array}$ & $\begin{array}{c}\text { Arus } \\
\text { listrik } \\
(\mathbf{A})\end{array}$ & $\begin{array}{c}\text { Resistansi } \\
\text { pembumian } \\
(\mathbf{O h m})\end{array}$ \\
\hline 1 & $\mathrm{~T} 2$ & 50 & 5,5 & 9,1 & 50 & 4,9 & 10,2 \\
\hline 2 & $\mathrm{X}$ & 50 & 5,0 & 10 & 50 & 4,5 & 11,11 \\
\hline 3 & $\mathrm{Y}$ & 50 & 5,8 & 8,6 & 50 & 4,2 & 11,9 \\
\hline
\end{tabular}

Pada Tabel 1 terlihat bahwa hasil pengukuran resistansi pembumian metode tiga titik menggunakan alat ukur Volt-Ampere meter tidak didapatkan nilai hasil pengukuran yang sama. Hal tersebut dikarenakan pada metode ini nilai resistansi pembumian tidak langsung terukur pada alat ukur. Resistansi pembumian didapat dari nilai tegangan yang terukur pada Volt meter dibagi dengan nilai arus listrik yang terukur pada Ampere meter. 
Hasil pengukuran resistansi pembumian pada Tabel 2 terdapat dua nilai hasil pengukuran yang sama yaitu 8,8 Ohm pada elektroda pembumian 1 dan $10 \mathrm{Ohm}$ pada elektroda pembumian 2. Kedua nilai yang sama tersebut didapat pada posisi jarak elektroda $\mathrm{E}-\mathrm{C}=10 \mathrm{~m}$ dan $\mathrm{E}-\mathrm{C}=15 \mathrm{~m}$. Pada kedua titik tersebut kondisi tanahnya homogen sehingga didapat nilai hasil pengukuran yang sama.

Tabel 2. Hasil pengukuran resistansi pembumian metode dua titik menggunakan earth tester

\begin{tabular}{|c|c|c|c|}
\hline \multirow{2}{*}{ No. } & \multirow{2}{*}{$\begin{array}{c}\text { Jarak } \\
\text { elektroda }\end{array}$} & Elektroda pembumian 1 & Elektroda pembumian 2 \\
\cline { 3 - 4 } & & 9,0 & 9,8 \\
\hline 1 & E-C $=5 \mathrm{~m}$ & 8,8 & 10 \\
\hline 2 & E-C $=10 \mathrm{~m}$ & 8,8 & 10 \\
\hline 3 & E-C $=15 \mathrm{~m}$ & 8,5 & 10,5 \\
\hline 4 & E-C $=20 \mathrm{~m}$ & & \multicolumn{2}{|c|}{ Resistans pembumian (Ohm) } \\
\hline
\end{tabular}

Pada Tabel 3 hasil pengukuran resistansi pembumian metode tiga titik menggunakan earth tester terdapat tiga hasil pengukuran yang nilainya sama yaitu $8,8 \mathrm{Ohm}$ pada elektroda pembumian 1 dan 10 Ohm pada elektroda pembumian 2. Ketiga nilai yang sama tersebut didapat pada pengukuran dengan posisi jarak elektroda E-C $=5 \mathrm{~m}$; E-P : $15 \mathrm{~m}, \mathrm{E}-\mathrm{C}=10 \mathrm{~m}$; E-P : $15 \mathrm{~m}$, dan E-C $=10 \mathrm{~m}$; E-P : $20 \mathrm{~m}$.

Tabel 3. Hasil pengukuran resistansi pembumian metode tiga titik menggunakan earth tester

\begin{tabular}{|c|c|c|c|}
\hline \multirow{2}{*}{ No. } & \multirow{2}{*}{ Jarak elektroda bantu } & \multicolumn{2}{|c|}{ Resistansi pembumian (Ohm) } \\
\cline { 3 - 4 } & & Elektroda pembumian 1 & Elektroda pembumian 2 \\
\hline 1 & E-C $=5 \mathrm{~m} ;$ E-P $: 10 \mathrm{~m}$ & 9,2 & 9,5 \\
\hline 2 & E-C $=5 \mathrm{~m} ; \mathrm{E}-\mathrm{P}: 15 \mathrm{~m}$ & 8,8 & 10 \\
\hline 3 & E-C $=5 \mathrm{~m} ; \mathrm{E}-\mathrm{P}: 20 \mathrm{~m}$ & 8,5 & 10,5 \\
\hline 4 & E-C $=10 \mathrm{~m} ; \mathrm{E}-\mathrm{P}: 15 \mathrm{~m}$ & 8,8 & 10 \\
\hline 5 & E-C $=10 \mathrm{~m} ; \mathrm{E}-\mathrm{P}: 20 \mathrm{~m}$ & 8,8 & 10 \\
\hline
\end{tabular}

Gambar 5 menunjukkan grafik perbandingan homogenitas pengukuran dari ketiga metode pengukuran yang digunakan pada elektroda pembumian 1. Berdasarkan hasil perbandingan, dapat dilihat bahwa metode ketiga menghasilkan pengukuran yang lebih homogen jika dibandingkan dengan metode lainnya.

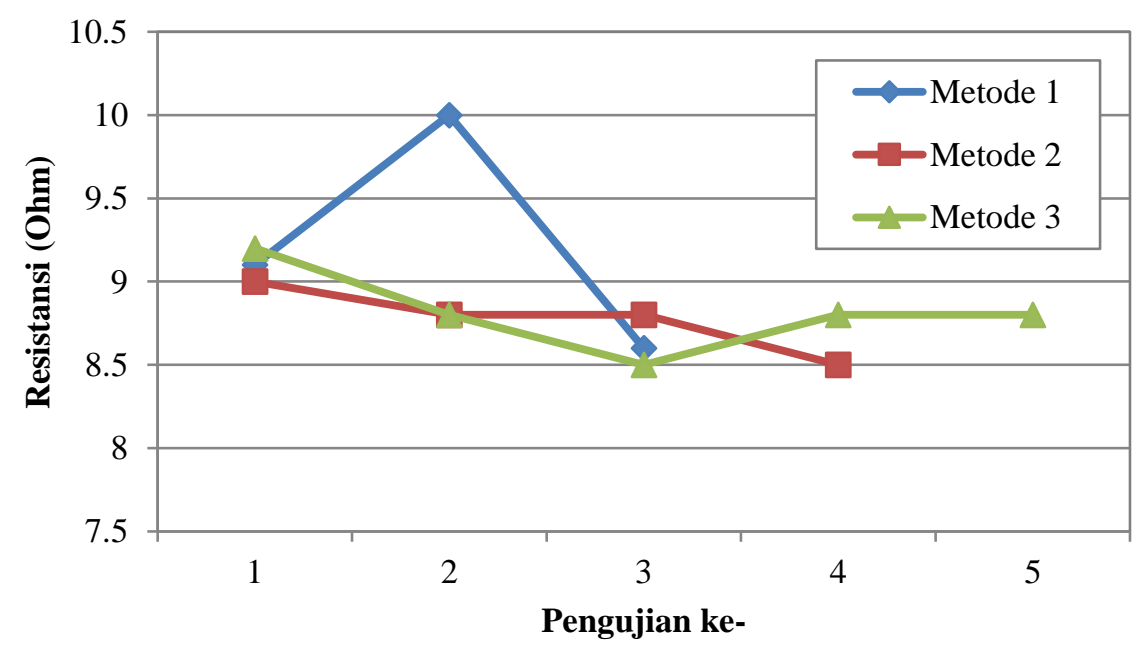

Gambar 5. Perbandingan pengukuran resistansi elektroda pembumian 1 
Gambar 6 menunjukkan grafik perbandingan homogenitas pengukuran dari ketiga metode pengukuran yang digunakan pada elektroda pembumian 2. Berdasarkan hasil perbandingan, dapat dilihat bahwa metode ketiga juga menghasilkan pengukuran yang lebih homogen jika dibandingkan dengan metode lainnya.

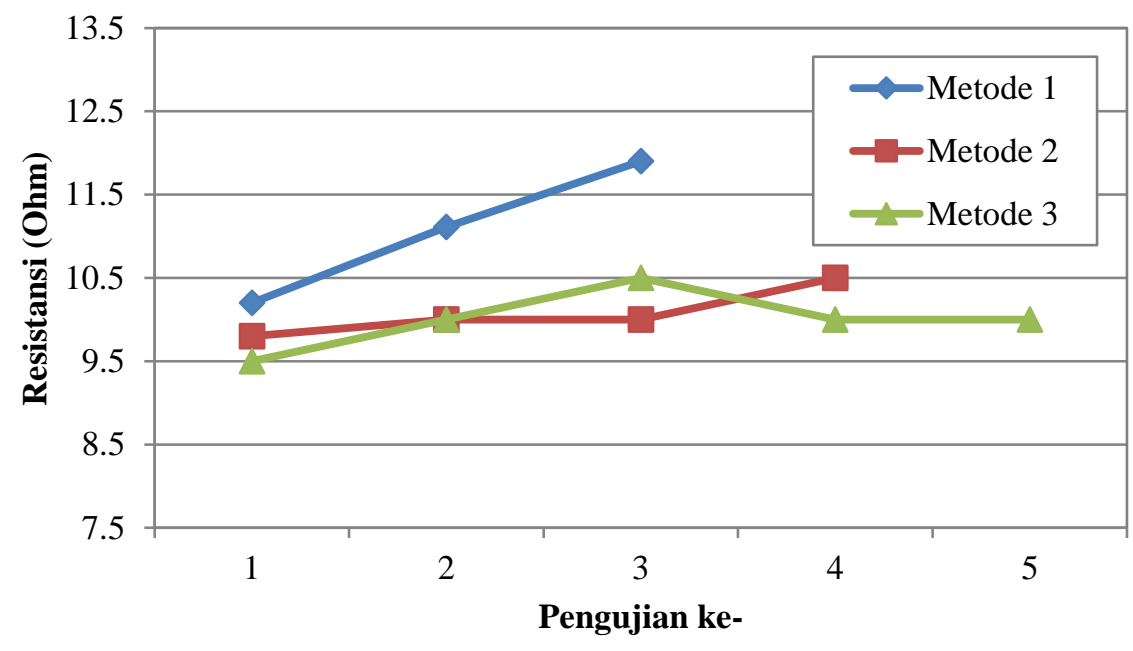

Gambar 6. Perbandingan pengukuran resistansi elektroda pembumian 2

\section{KESIMPULAN}

Berdasarkan hasil penelitian dapat disimpulkan bahwa pengukuran resistansi pembumian metode tiga titik menggunakan alat ukur Volt-Ampere meter tidak didapat hasil pengukuran yang nilainya homogen. Pada pengukuran resistansi pembumian metode dua titik dan tiga titik menggunakan alat ukur earth tester didapat hasil pengukuran yang nilainya sama. Namun demikian pada metode tiga titik menggunakan earth tester lebih banyak hasil pengukuran yang nilainya sama dibandingkan dengan metode dua titik. Dari ketiga metode pengukuran resistansi pembumian tersebut yang paling baik adalah metode tiga titik menggunakan alat ukur earth tester dibandingkan dua metode lainnya karena mampu menghasilkan hasil pengukuran yang nilainya homogen, serta metode ini tidak memerlukan sumber tegangan dari luar. Penelitian selanjutnya diperlukan untuk membandingkan pengukuran resistansi pembumian dengan melibatkan variabel lainnya.

\section{UCAPAN TERIMA KASIH}

Terima kasih diucapkan kepada Laboratorium Instalasi Listrik, Jurusan Teknik Elektro, Politeknik Negeri Bandung yang telah memfasilitasi peralatan yang diperlukan dalam pelaksanaan penelitian ini.

\section{REFERENSI}

[1] SNI 0225:2011, "Persyaratan Umum Instalasi Listrik 2011,” BSN, 2011.

[2] SNI 04-0225:2000, “Persyaratan Umum Instalasi Listrik 2000,” BSN, 2000.

[3] D. Setiawan, "Analisis Pengaruh Penambahan Garam dan Arang Sebagai Soil Treatment dalam Menurunkan Resistansi Pentanahan Variasi Kedalaman Elektrode,” Transient, vol. 7, no. 2, pp. 416-423, 2018.

[4] J. Jammaluddin, "Perencanaan Sistem Pentanahan Tenaga Listrik Terintegrasi pada Bangunan," Journal of Electrical and Electronic Engineering (UMSIDAJEEE-U), vol. 1, no. 1, pp. 29-33, 2017.

[5] A. Budiman, "Analisa Tahanan Pembumian Peralatan Gedung Laboratorium Teknik Universitas Borneo Tarakan yang Menggunakan Eelektrode Pasak Tunggal Panjang 2 Meter," Jurnal JPE, vol. 21, no. 1, pp. 75-80, 2017.

[6] A. Budiman, "Analisa Perbandingan Tahanan Pembumian Peralatan Elektrode Pasak pada Gedung Laboratorium Teknik Universitas Borneo Tarakan,” Jurnal Nasional Teknik Elektro, vol. 6, no. 3, pp. 152$158,2017$. 
[7] M. Saini, A. M. Yunus, and A. Pangkung, "Pengembangan Sistem Penangkal Petir dan Pentanahan Elektrode Rod dan Plat," Journal INTEK, vol. 3, no. 2, pp. 66-71, 2016.

[8] T. Siahaan and S. Laia "Studi Pembumian Peralatan dan Sistem Instalasi Listrik pada Gedung Kantor BICT PT. Pelindo I (Persero) Belawan,” Jurnal Teknik Elektro, vol. 8, no. 2, pp. 96-101, 2019.

[9] D. E. Putra and J. Udi, "Pengukuran Grounding SDP Panel Distribusi Instalasi Rekam Medis RSUP Dr. Mohammad Hoesin Palembang," Jurnal Ampere, vol. 3, no. 1, pp. 128-139, 2018.

[10] A. Sunawar, "Analisis Pengaruh Temperatur dan Kadar Garam Terhadap Hambatan Jenis Tanah," SETRUM, vol. 2, no. 1, pp. 16-21, 2013.

[11] A. Devi, M. Yul, and G. Herri "Perbaikan Tahanan Pentanahan dengan menggunakan Bentonit Teraktivasi,” ELECTRICIAN-Jurnal Rekayasa dan Teknologi Elektro, vol. 10, no. 1, pp. 44-53, 2016. 